\title{
Cross talk between P2 purinergic receptors modulates extracellular ATP-mediated interleukin-10 production in rat microglial cells
}

\author{
Dong Reoyl Seo ${ }^{1 *}$, Soo Yoon $\mathrm{Kim}^{1,2 *}$, \\ Kyung You Kim ${ }^{1}$, Hwan Goo Lee ${ }^{1,2}$, \\ Ju Hyun Moon ${ }^{1,2}$, Jae Souk Lee ${ }^{1,2}$, \\ Se Hoon Lee ${ }^{1,2}$, Seung U. Kim ${ }^{3,4}$ \\ and Yong Beom Lee $e^{1,2,3,5}$ \\ ${ }^{1}$ Neuroscience Graduate Program \\ ${ }^{2}$ BK21 Division of Cell Transformation and Restoration \\ ${ }^{3}$ Brain Disease Research Center \\ Ajou University School of Medicine \\ Suwon 443-721, Korea \\ ${ }^{4}$ Division of Neurology, Department of Medicine \\ University of British Columbia \\ Vancouver, British Columbia, Canada V6T 1 Z3 \\ ${ }^{5}$ Corresponding author: Tel, 82-31-219-4558; \\ Fax, 82-31-216-6381; E-mail, yblee@ ajou.ac.kr \\ *These authors contributed equally to this work.
}

Accepted 19 November 2007

Abbreviations: $\mathbb{I P}_{3}$, inositol phosphates; M-MLV, Moloney murine leukemia virus; ROS, reactive oxygen species

\begin{abstract}
Previously we demonstrated that ATP released from LPS-activated microglia induced IL-10 expression in a process involving $\mathrm{P} 2$ receptors, in an autocrine fashion. Therefore, in the present study we sought to determine which subtype of $\mathrm{P} 2$ receptor was responsible for the modulation of IL-10 expression in ATP-stimulated microglia. We found that the patterns of IL-10 production were dose-dependent $(1,10,100$, $1,000 \mu \mathrm{M})$ and bell-shaped. The concentrations of ATP, ATP- $\gamma$ S, ADP, and ADP- $\beta$ S that showed maximal IL-10 release were $100,10,100$, and $100 \mu \mathrm{M}$ respectively. The rank order of agonist potency for IL-10 production was 2'-3'-0-(4-benzoyl)-benzoyl ATP (BzATP) = dATP > 2-methylthio-ADP (2-meSADP). On the other hand, 2-methylthio-ATP (2-meSATP), $\alpha, \beta$-methylene ATP $(\alpha, \beta-$ meATP), UTP, and UDP did not induce the release of IL-10 from microglia. Further, we obtained evidence of crosstalk between $\mathrm{P} 2$ receptors, in a situation where intracellular $\mathrm{Ca}^{2+}$ release and/or CAMP-activated PKA were the main contributors to extracellular ATP-(or
\end{abstract}

ADP)-mediated IL-10 expression, and IL-10 production was down- regulated by either MRS2179 (a P2Y ${ }_{1}$ antagonist) or 5'-AMPS (a P2Y ${ }_{11}$ antagonist), indicating that both the $P 2 Y_{1}$ and $P 2 Y_{11}$ receptors are major receptors involved in IL-10 expression. In addition, we found that inhibition of IL-10 production by high concentrations of ATP- $\gamma \mathrm{S}(100 \mu \mathrm{M})$ was restored by TNP-ATP (an antagonist of the $\mathrm{P}_{2} \mathrm{X}_{1}, \mathrm{P}_{2} \mathrm{X}_{3}$, and $\mathrm{P}_{2} \mathrm{X}_{4}$ receptors), and that IL-10 production by 2-meSADP was restored by 2meSAMP (a P2Y ${ }_{12}$ receptor antagonist) or pertussis toxin (PTX; a $G_{i}$ protein inhibitor), indicating that the $\mathrm{P}_{2} \mathrm{X}_{1}, \mathrm{P}_{2} \mathrm{X}_{3}, \mathrm{P}_{2} \mathrm{X}_{4}$ receptor group, or the $\mathrm{P} 2 \mathrm{Y}_{12}$ receptor, negatively modulate the $\mathrm{P}_{2} \mathrm{Y}_{11}$ receptor or the $\mathrm{P} 2 \mathrm{Y}_{1}$ receptor, respectively.

Keywords: adenosine diphosphate; adenosine triphosphate; calcium; cyclic AMP; cyclic AMP-dependent protein kinases; inositol 3-phosphate; interleukin-10; microglia; receptors, purinergic P2

\section{Introduction}

Extracellular purine (ATP, ADP) and pyrimidine (UTP, UDP) nucleotides mediate their effects via P2 receptors (Ralevic and Burnstock, 1998). P2 receptors consist of ligand-gated intrinsic ion channels, P2X receptors, and G-protein-coupled P2Y receptors. Stimulation of $\mathrm{P} 2 \mathrm{X}$ receptors $\left(\mathrm{P}_{2} \mathrm{X}_{1-}\right.$ $\mathrm{P}_{2} \mathrm{X}_{7}$ ) causes $\mathrm{Ca}^{2+}$ and $\mathrm{Na}^{+}$influx from the extracellular space with accompanying plasma membrane depolarization (Khakh and North, 2006). The $P 2 Y$ receptors are composed of eight subtypes in mammals: $\mathrm{P}_{2} \mathrm{Y}_{1}, \mathrm{P}_{2} \mathrm{Y}_{2}, \mathrm{P}_{2} \mathrm{Y}_{4}, \mathrm{P}_{2} \mathrm{Y}_{6}, \mathrm{P}_{2} \mathrm{Y}_{11}, \mathrm{P} 2 \mathrm{Y}_{12}$, $P 2 Y_{13}$, and $P 2 Y_{14}$. The $P 2 Y_{1}, P 2 Y_{12}$, and $P 2 Y_{13}$ receptors are preferentially activated by ADP whereas $\mathrm{P}_{2} \mathrm{Y}_{6}$ is activated by UDP (Abbracchio et al., 2006). The $P 2 Y_{11}$ receptor prefers ATP as an agonist (Communi et al., 1997) whereas the $\mathrm{P}_{2} \mathrm{Y}_{2}$ (Lustig et al., 1993) and $\mathrm{P}_{2} \mathrm{Y}_{4}$ receptors are equally sensitive to ATP and UTP (Communi et al., 1995). The $\mathrm{P}_{2} \mathrm{Y}_{14}$ receptor is activated by the nucleotide sugar UDP-glucose (Brunschweiger and Muller, 2006). The $P 2 Y_{1}, P 2 Y_{2}, P 2 Y_{4}, P 2 Y_{6}$, and $P 2 Y_{11}$ receptors are coupled to $G_{q}$, promoting PLCcatalyzed generation of an inositol phosphate $\left(\mathrm{IP}_{3}\right)$ and subsequent release of intracellular calcium 
(Ralevic and Burnstock, 1998). The $\mathrm{P} 2 \mathrm{Y}_{12}, \mathrm{P} 2 \mathrm{Y}_{13}$, and $\mathrm{P}_{2} \mathrm{Y}_{14}$ receptors are coupled to $\mathrm{G}_{\mathrm{i} / \mathrm{o}}$, inhibiting adenyl cyclase (Hollopeter et al., 2001).

Recent studies have suggested that activated immune cells secrete ATP into the extracellular space, to release cytokines by activation of $\mathrm{P} 2$ receptors (Di Virgilio and Solini, 2002). Extracellular ATP is known to be a potential mediator of inducible iNOS expression (Ohtani et al., 2000) and TNF- $\alpha$ release in rat microglia, via $\mathrm{P}_{2} \mathrm{X}_{7}$ receptors (Hide et al., 2000). The presence of the $\mathrm{P}_{2} \mathrm{X}_{7}$ receptor in microglia is consistent with involvement of this receptor in the inflammatory process [e.g., in the production of proinflammatory cytokines, nitric oxide, and reactive oxygen species (ROS)] and cytotoxicity (Di Virgilio et al., 1999; Parvathenani et al., 2003). In addition, ATP evokes the production of IL-6, a mediator of inflammation, in the microglial cell line MG-5 (Shigemoto-Mogami et al., 2001), and induces maturation and release of IL- $1 \beta$ by activating the IL- $1 \beta$-converting enzyme/ caspase 1 (Sanz and Di Virgilio, 2000). Further, recent studies have reported that $\mathrm{P}_{2} \mathrm{X}_{4}$ receptors are involved in pain transmission (Tsuda et al., 2003) and that during microglial activation, $P 2 Y_{12}$ receptors, which mediate the movement of microglial projections, are down-regulated (Haynes et al., 2006), but $\mathrm{P} 2 \mathrm{Y}_{6}$ receptors are up-regulated and trigger phagocytosis (Koizumi et al., 2007). Together, these results suggest that $\mathrm{P} 2$ receptors play a critical role in brain inflammation by regulating the production of inflammatory mediators and microglial activation.

Our previous study demonstrated that ATP released from LPS-activated microglia, and metabolites of ATP, induced IL-10 expression in a process involving $\mathrm{P} 2$ receptors, in an autocrine fashion, indicating that $\mathrm{P} 2$ receptors also have a function that counteracts the effects of proinflammatory mediators by participating in the production of the anti-inflammatory cytokine IL-10 (Seo et al., 2004). Therefore, we sought to determine which subtype of P2 receptors is responsible for the modulation of IL-10 expression in ATP-stimulated microglia.

\section{Materials and Methods}

\section{Microglial cell culture}

Microglial cultures were prepared from the brains of 3 day-old Sprague-Dawley rats as described previously (Kim et al., 2002). Briefly, whole brains were dissected into small cubes, incubated in D-PBS (JBI, Daegu, Korea) containing 0.1\% trypsin and $40 \mu \mathrm{g} / \mathrm{ml}$ DNase I for $15 \mathrm{~min}$ at $37^{\circ} \mathrm{C}$, and dissociated into single cells by gentle pipetting.
Dissociated cells were suspended in DMEM (JBI) containing $5 \%$ horse serum, $5 \mathrm{mg} / \mathrm{ml}$ glucose, 100 $\mathrm{U} / \mathrm{ml}$ penicillin and $100 \mu \mathrm{g} / \mathrm{ml}$ streptomycin, and plated on poly-D-lysine-coated T-75 culture flasks, and incubated at $37^{\circ} \mathrm{C}$ in incubator with $5 \% \mathrm{CO}_{2} /$ $95 \%$ air atmosphere. After 2-4 weeks of growth in flasks, microglia floating in the medium were collected and grown in separate 6- or 96-well plates.

\section{RT-PCR analysis}

To determine which subtypes of $\mathrm{P} 2 \mathrm{X}$ and $\mathrm{P} 2 \mathrm{Y}$ receptors are expressed by rat microglia, microglial cells $\left(1 \times 10^{6}\right.$ cells/well) were plated into 6 -well plates in DMEM $(\mathrm{JBI})$ containing $5 \%$ horse serum (JBI). Total RNA was extracted using Trizol (Life Technologies, Rockville, MD). Total RNA from each sample was subjected to DNase I treatment and then processed for the first strand cDNA synthesis using Moloney murine leukemia virus (M-MLV) reverse transcriptase (Life Technologies). $5 \mu$ of each CDNA products was amplified by PCR using specific sense and antisense primers designed from the CDNA sequences for $\mathrm{P} 2$ receptors: $\mathrm{P} 2 \mathrm{X}_{1}$, 5'-AGAGGCACTACTACAAGCAGAA-3' (sense) and 5'-GGTAAGGCTGTGGGAAAGA-3' (antisense); P2X 2 , 5'-GAATCAGAGTGCAACCCCAA-3' (sense) and 5'-TCACAGGCCATCTACTTGAG-3' (anti-

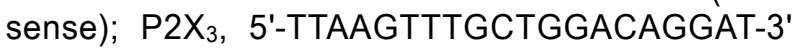
(sense) and 5'-GTTCCCATATACCAGCACAT-3' (antisense); P2X $\mathrm{X}_{4}, 5$ '-TCCCTTCTGCCCCATATTCC3' (sense) and 5'-TTCATCTCCCCCGAAAGACC-3' (antisense); P2X ${ }_{5}, 5^{\prime}$-CGACCTGGTACTTATCTACCTC-3' (sense) and 5'-ACGTTCACAATGGCATTC3' (antisense); P2X 6 , 5'-GCCCAGAGCATCCTTCTGTTC-3' (sense) and 5'-CGTGGCTGTATGTCCCCATC-3' (antisense); P2X ${ }_{7}, 5^{\prime}$-AACAGTGCCATTCTGACC-3' (sense) and 5'-GCCACCTCTGTAAAGTTCTC-3' (antisense); P2Y, 5'-GGCAGGCTCAAGAAGAAGAAT-3' (sense) and 5'-ATCACACATTTCTGGGGTCTG-3' (antisense); P2Y 2 , 5'AGCTCTTTAGCCATTTTGTG-3' (sense) and 5'CGGAAGGAGTAATAGAGGGT-3' (antisense); P2Y 5'-ACTGTCTTTGCTGTCTGCTT-3' (sense) and 5'AGACAGCTATTAGCACTGGC-3' (antisense); P2Y, 5'-GTCTACCGTGAGGATTTCAA-3' (sense) and 5'-CTAGGTATCGCTGGAAGCTA-3' (antisense); P2 $_{12}$, 5'-CTCCACCACCTACATGTTTC-3' (sense) and 5'-AAGAGGATGCTGCAGTAGAG-3' (antisense); P2Y ${ }_{13}, 5^{\prime}$-TGCACTTTCTCATCCGTGGT-3' (sense) and 5'-GGCAGGGAGATGAGGAACAT-3' (antisense)

\section{Measurement of IL-10}

To evaluate the effects of ATP on IL-10 production, 
microglial cells $\left(3 \times 10^{4}\right.$ cells/well $)$ were plated into 96-well plates in DMEM containing $5 \%$ horse serum. The amount of IL-10 in the supernatant was measured by ELISA. To assess which purinergic receptor was involved in the microglial IL-10 production, microglia cells were treated with $\mathrm{P} 2$ receptor agonists: ATP, ADP, adenosine 5'-O-(3-thiotriphosphate) (ATP- $\gamma-S)$, adenosine 5'-O-(2-thiodiphosphate) (ADP- $\beta$-S), 2-methylthio-ATP (2-meSATP), 2 -methylthio-ADP (2-meSADP), $\alpha, \beta$-methylene ATP ( $\alpha, \beta$-meATP), 2',3'-(benzoyl-4-benzoyl)-ATP (BzATP), UTP, UDP, or dATP (Sigma, St. Louis, MO); P2 receptor antagonists: trinitrophenyl-substituted ATP (TNP-ATP), adenosine 5'-triphosphate 2',3'-acylic dialcohol (oxidized ATP; oATP), 2'-deoxy- $\mathrm{N}^{6}$-methyladenosine-3',5'-bisphosphate (MRS2179), 2methylthioadenisine 5'-monophosphate (2-meSAMP), 5'-O-thiomnophosphate (5'-AMPS) (Sigma, St. Louis, $\mathrm{MO}$ ); $\mathrm{Ca}^{2+}$ chelators: EGTA (Sigma, St. Louis, MO), bisaminophenoxyethane tetraacetic acid-acetoxymethyl ester (BAPTA-AM; Calbiochem, San Diego, $\mathrm{CA}$ ); $\mathrm{IP}_{3}$ inhibitor, Xes-C (Sigma, St. Louis, MO); adenylate cyclase inhibitor, SQ22536 (Sigma, St. Louis, MO); PKA inhibitor, H-89 (Sigma, St. Louis, $\mathrm{MO}$ ); $\mathrm{G}_{\mathrm{i}}$ protein inhibitor, pertussis toxin (PTX; Sigma, St. Louis, MO). For IL-10 assay, we used Cytosets kit for rat IL-10 (Biosource, Camarillo, $\mathrm{CA})$ according to the manufacturer's protocol.

\section{Statistical analysis}

All statistical comparisons in this study were performed using one-way ANOVA with the Tukey-Kramer multiple comparisons test, and data are expressed as mean \pm SEM of triplicate samples. A value of $P$ $<0.05$ was considered statistically significant.

\section{Results}

Characterization of ATP-(or ATP- $\gamma$ S)-induced IL-10
release, and ADP-(or ADP- $\beta$ S)-induced IL-10 release

To characterize IL-10 expression by ATP-stimulated microglia, microglial cells were treated with various concentrations $(1,10,100,1,000 \mu \mathrm{M})$ of ATP, ADP, ATP- $\gamma$ S (a hydrolysis-resistant analog of ATP), or ADP- $\beta S$ (a hydrolysis-resistant analog of ADP). We found that the patterns of IL-10 production were dose-dependent and bell-shaped (Figure 1). Interestingly, the concentrations of ATP and ATP$\gamma S$ that showed maximal IL-10 release were different. ATP-induced IL-10 release peaked at an ATP concentration of $100 \mu \mathrm{M}(811.51 \pm 29.59 \mathrm{pg} /$ $\mathrm{ml} \mathrm{IL-10)}$ and was sustained to $1,000 \mu \mathrm{M}(750.15$ $\pm 5.66 \mathrm{pg} / \mathrm{ml}$ ). On the other hand, ATP- $\gamma \mathrm{S}-$ induced IL-10 release peaked at an ATP- $\gamma \mathrm{S}$ concentration of $10 \mu \mathrm{M}(930.65 \pm 30.94 \mathrm{pg} / \mathrm{ml})$ but dropped to $480.88 \pm 18.52 \mathrm{pg} / \mathrm{ml}$ at $100 \mu \mathrm{M}(P<$ $0.01)$. In the case of ADP, ADP-induced or ADP- $\beta S$-induced IL-10 release peaked at a concentration of $100 \mu \mathrm{M}$, but treatment with $1,000 \mu \mathrm{M}$ ADP (IL-10 release of $186.27 \pm 20.70 \mathrm{pg} / \mathrm{ml}$ ) or $1,000 \mu \mathrm{M}$ ADP- $\beta S$ (IL-10 release of $475.10 \pm$ $30.96 \mathrm{pg} / \mathrm{ml}$ ) appeared to induce less IL-10 release than did treatment with $100 \mu \mathrm{M}$ ADP (485.26 \pm $20.33 \mathrm{pg} / \mathrm{ml}$ ) or $100 \mu \mathrm{M}$ ADP- $\beta$ S (721.43 \pm 35.20 $\mathrm{pg} / \mathrm{ml})(P<0.01)$. These results indicate that 100
A

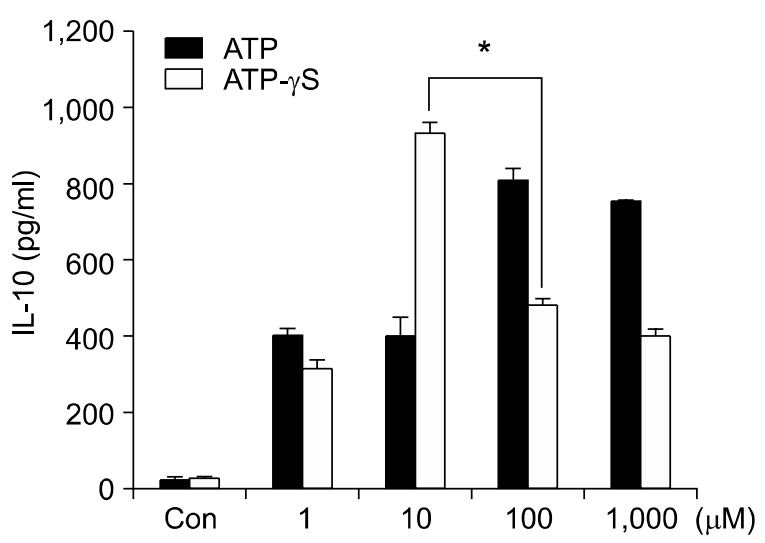

B

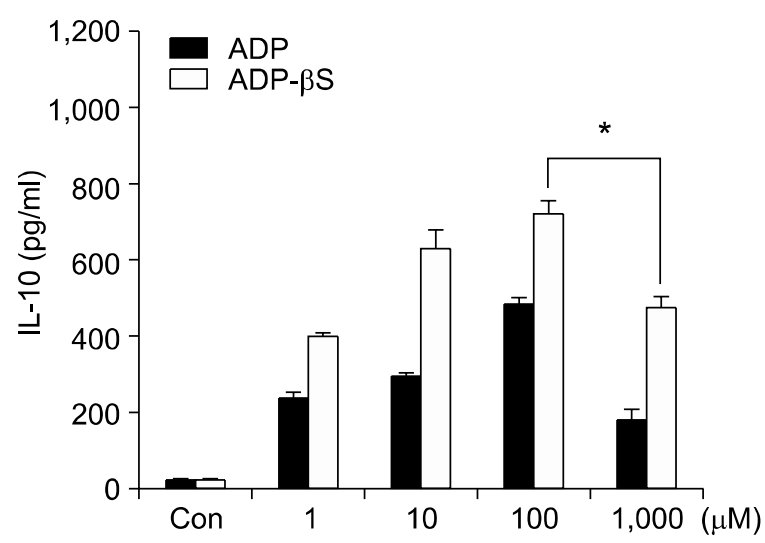

Figure 1. Characterization of ATP (or ATP- $\gamma$ S)- or ADP (or ADP- $\beta$ S)-induced IL-10 release. Microglial cells $\left(3 \times 10^{4}\right.$ cells/well) were treated with (A) ATP or ATP- $\gamma-S$, (B) ADP or ADP- $\beta$-S at the indicated concentrations. The amount of IL-10 was measured $24 \mathrm{~h}$ after treatment with ATP (ATP- $\gamma$-S) or ADP $(A D P-\beta-S)$. Data shown are mean \pm SEM of triplicate samples. The figure shows one representative of five independent experiments. ${ }^{*} P<0.01$ compared to $10 \mu \mathrm{M}$ ATP- $\gamma$ S or $100 \mu \mathrm{M}$ ADP- $\beta$ S. 
$\mu \mathrm{M}$ ATP- $\gamma \mathrm{S}$ or $1,000 \mu \mathrm{M}$ ADP- $\beta$ S inhibit IL-10 production by affecting distinct subtypes of the P2 receptor involved in IL-10 expression. We found no loss of cell viability in the presence of either 100 $\mu \mathrm{M}$ ATP- $\gamma \mathrm{S}$ or 1,000 $\mu \mathrm{M}$ ADP- $\beta \mathrm{S}$ (data not shown).

\section{Expression of mRNAs encoding the P2X and P2Y receptors}

To determine which subtypes of $\mathrm{P} 2 \mathrm{X}$ and $\mathrm{P} 2 \mathrm{Y}$

\section{A}

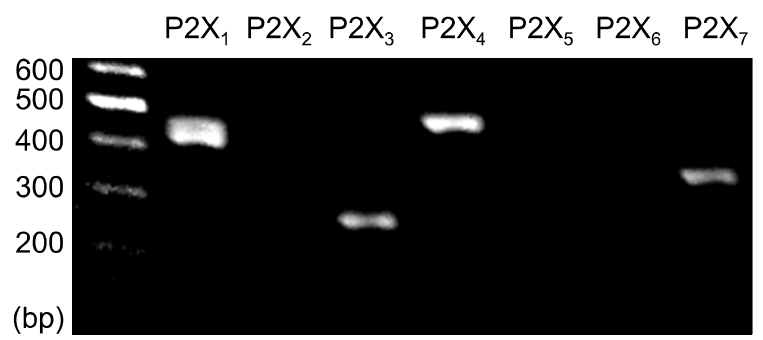

B

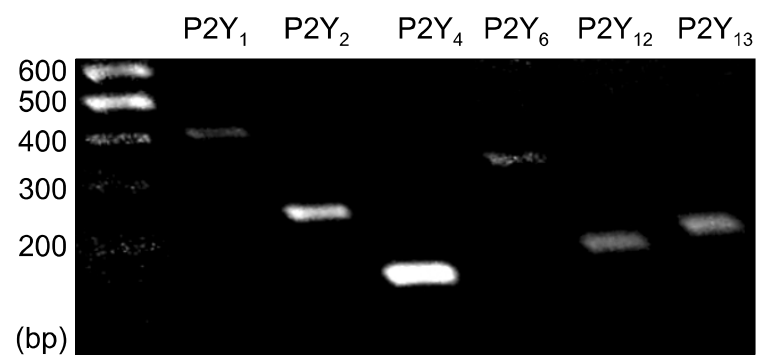

Figure 2. Expression of $P 2 X$ and $P 2 Y$ receptors mRNA. RT-PCR analysis of $\mathrm{P} 2$ receptor $\mathrm{mRNA}$ expression in microglial cells was done with primers specific for distinct P2 receptors subtypes. CDNA products were analyzed by $1.5 \%$ agarose gel electrophoresis. A representive gel with ethidium bromide-stained cDNA fragments of the $\mathrm{P} 2$ receptors. receptors are expressed by rat microglia, mRNA was isolated from microglial cells and analyzed by RT-PCR. Amplified PCR products of the expected sizes were obtained for $\mathrm{P}_{2} \mathrm{X}_{1}(434 \mathrm{bp}), \mathrm{P}_{2} \mathrm{X}_{3}(272$ bp), $\mathrm{P}_{2} \mathrm{X}_{4}(489 \mathrm{bp})$, and $\mathrm{P}_{2} \mathrm{X}_{7}(358 \mathrm{bp}$ ) receptor mRNAs (Figure 2A). Similarly, amplified PCR products of the expected sizes were obtained for the $\mathrm{P}^{2} \mathrm{Y}_{1}$ (411 bp), $\mathrm{P}_{2} \mathrm{Y}_{2}$ (244 bp), $\mathrm{P} \mathrm{Y}_{4}$ (149 bp), $\mathrm{P} \mathrm{Y}_{6}$ (325 bp), $\mathrm{P}_{2} \mathrm{Y}_{12}(168 \mathrm{bp})$, and $\mathrm{P}^{2} \mathrm{Y}_{13}(185 \mathrm{bp})$ receptor mRNAs from microglial cell total mRNA (Figure 2B). A recent study reported that microglia express various receptors for ATP including both $\mathrm{P} 2 \mathrm{X}$ receptors $\left(\mathrm{P} 2 \mathrm{X}_{3}, \mathrm{P} 2 \mathrm{X}_{4}, \mathrm{P} 2 \mathrm{X}_{5}, \mathrm{P} 2 \mathrm{X}_{7}\right)$ and $\mathrm{P} 2 \mathrm{Y}$ receptors $\left(P 2 Y_{1}, P 2 Y_{2}, P 2 Y_{4}, P 2 Y_{6}, P 2 Y_{12}, P 2 Y_{13}\right)$ (Light et al., 2006). At this point, we could not test the expression of $\mathrm{P} 2 \mathrm{Y}_{11}$ receptor, because rat $\mathrm{P}_{2} \mathrm{Y}_{11}$ receptor has not been cloned.

\section{Effects of $\mathrm{P} 2$ receptor agonists on the release of IL-10 from microglial cells}

We next examined the effects of various concentrations $(1,10,100,300,1,000 \mu \mathrm{M})$ of agonists (2-meSATP, 2-meSADP, $\alpha, \beta$-meATP, BzATP, UTP, UDP, dATP) of the microglia-expressed P2 receptors (identified by RT-PCR) on the release of IL-10 from microglia. The agonists 2-meSADP, BzATP, and dATP increased the release of IL-10 in a dose-dependent manner, but 2-meSATP, $\alpha, \beta$ meATP, UTP, and UDP did not (Figure 3). 2meSADP and BzATP showed the bell-shaped paradigm which has maximal IL-10 release at 100 $\mu \mathrm{M}$. On the other hand, dATP-induced IL-10 release was sustained as agonist concentrations rose to $1 \mathrm{mM}$. The rank order of agonist potency was BzATP $=$ dATP $>2$-meSADP. Because 2meSADP is an agonist for both $P 2 Y_{1}$ and $P 2 Y_{12}$ receptors, and both $\mathrm{P}_{2} \mathrm{X}_{7}$ agonist BzATP and dATP are potent $P 2 Y_{11}$ receptor agonists, these results indicate that purinergic modulation of IL-10 ex-

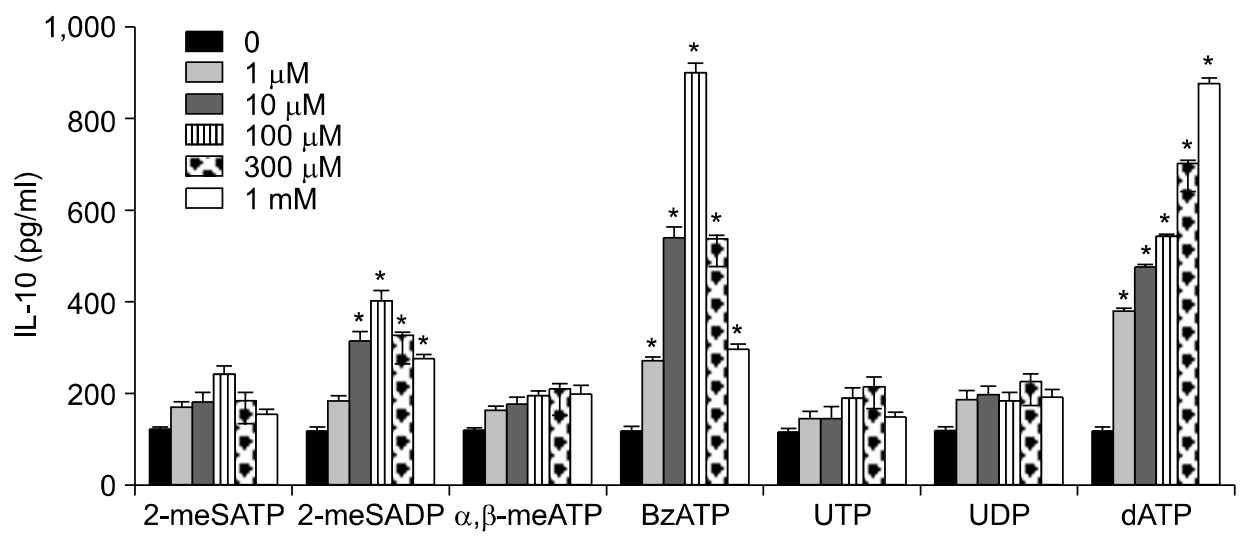

Figure 3. Effects of the P2 receptor agonist on the release of IL-10 from microglial cells. Microglial cells $\left(3 \times 10^{4}\right.$ cells/well) were treated with 2-meSATP, 2meSADP, $\alpha, \beta$-meATP, BzATP, UTP, UDP, and dATP at the indicated concentrations. The amount of IL-10 was measured $24 \mathrm{~h}$ after treatment. Data shown are mean \pm SEM of triplicate samples. The figure shows one representative of five independent experiments. ${ }^{*} P$ $<0.01$ compared to control. 
pression may be mediated by $\mathrm{P}_{2} \mathrm{X}_{7}, \mathrm{P}_{2} \mathrm{Y}_{1}, \mathrm{P}_{2} \mathrm{Y}_{11}$, and $\mathrm{P}_{2} \mathrm{Y}_{12}$ receptors.

\section{Effects of $\mathrm{P} 2$ receptor antagonists on the release of IL-10 from microglial cells}

To determine which subtype of $\mathrm{P} 2$ receptor was responsible for the modulation of IL-10 expression, we then examined the effects of the specific antagonist of the $\mathrm{P} 2 \mathrm{X}_{7}, \mathrm{P} 2 \mathrm{Y}_{1}, \mathrm{P} 2 \mathrm{Y}_{11}$, or $\mathrm{P} 2 \mathrm{Y}_{12}$ receptors, and an antagonist of the $P 2 X_{1}, P 2 X_{3}$, and $\mathrm{P}^{2} \mathrm{X}_{4}$ receptors. ATP- $\gamma \mathrm{S}(100 \mu \mathrm{M})$-induced $\mathrm{IL}-10$ release was restored by TNP-ATP (an antagonist of the $P 2 X_{1}, P 2 X_{3}$, and $P 2 X_{4}$ receptors) (Figure $4 A$ ).
2-meSADP $(100 \mu \mathrm{M})$-induced IL-10 release was inhibited by MRS2179 (a P2Y 1 antagonist), but 2meSAMP (a P2Y 12 antagonist) up-regulated 2meSADP $(100 \mu \mathrm{M})$-induced IL-10 release (Figure $4 \mathrm{~B})$. On the other hand, BzATP $(300 \mu \mathrm{M})$-induced IL-10 release was not restored by oATP (a P2X antagonist) (Figure 4C). BzATP $(100 \mu \mathrm{M})$-induced IL-10 release was inhibited by 5 '-AMPS (a P2Y 11 antagonist) (Figure 4D). These results indicate that both the $P 2 Y_{1}$ and $P 2 Y_{11}$ receptors are major receptors involved in IL-10 expression, and that the $\mathrm{P} 2 \mathrm{X}_{1}, \mathrm{P}_{2} \mathrm{X}_{3}, \mathrm{P}_{2} \mathrm{X}_{4}$ receptor group, or the $\mathrm{P} 2 \mathrm{Y}_{12}$ receptor, negatively modulates the $P_{2} Y_{11}$ receptor or the $\mathrm{P}_{2} \mathrm{Y}_{1}$ receptor, respectively.
A

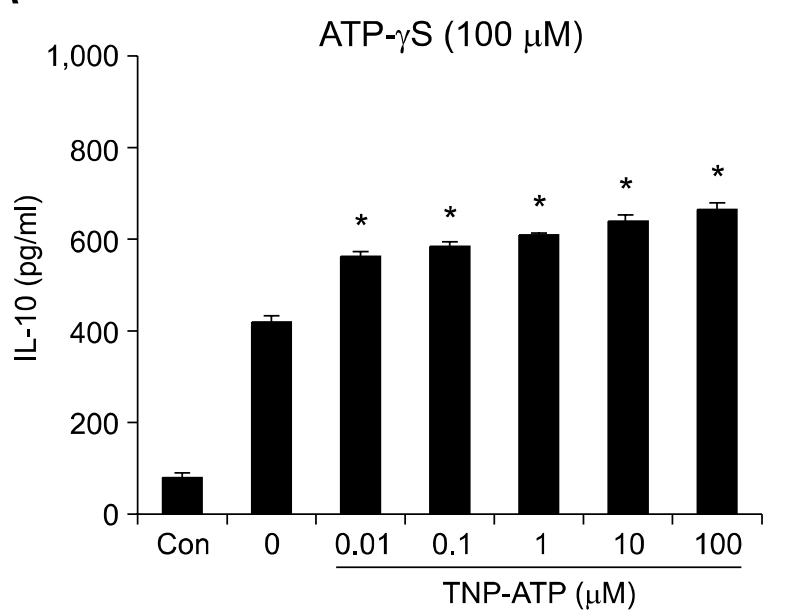

C

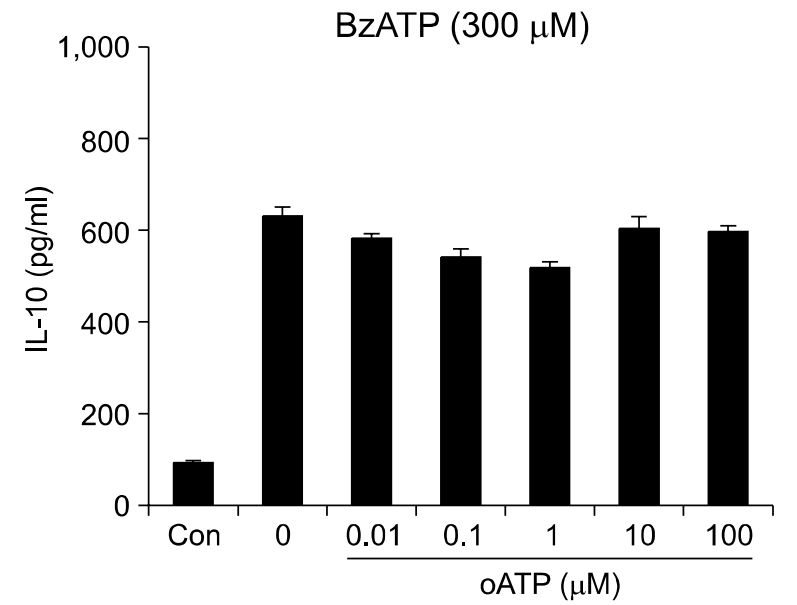

B

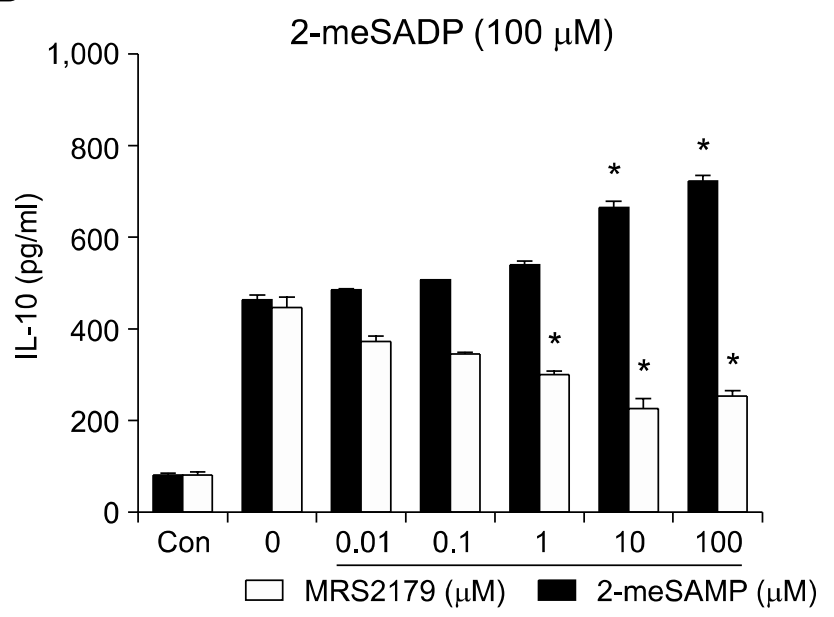

D

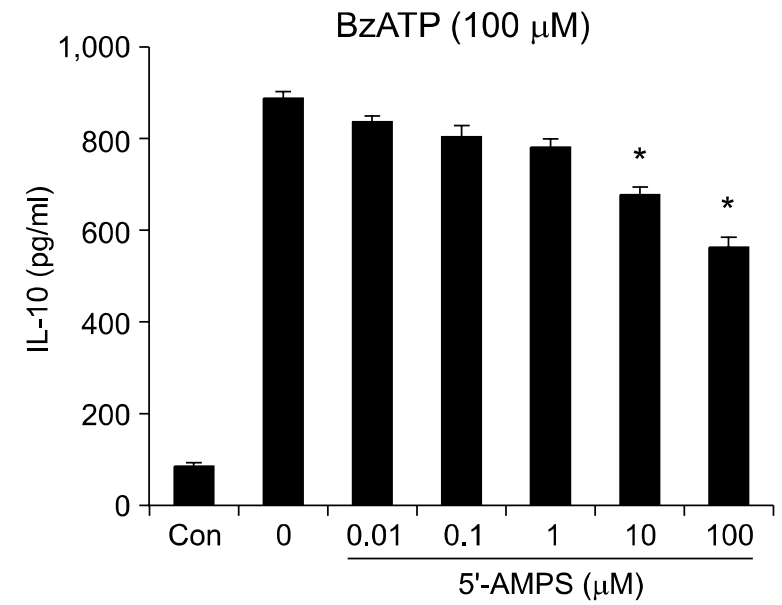

Figure 4. Effects of the P2 receptor antagonist on the release of IL-10 from microglial cells. Microglial cells $\left(3 \times 10^{4}\right.$ cells/well) were pretreated with TNP-ATP, MRS2179, 2-meSAMP, OATP, or 5'-AMPS for $30 \mathrm{~min}$ at the indicated concentrations, then treated with ATP- $\gamma-\mathrm{S}(100 \mu \mathrm{M}), 2$-meSADP (100 $\mu \mathrm{M})$, and BzATP $(100$ or $300 \mu \mathrm{M})$. The amount of IL-10 was measured $24 \mathrm{~h}$ after treatment. Data shown are mean \pm SEM of triplicate samples. The figure shows one representative of five independent experiments. ${ }^{*} P<0.01$ compared to the agonist alone. 
A

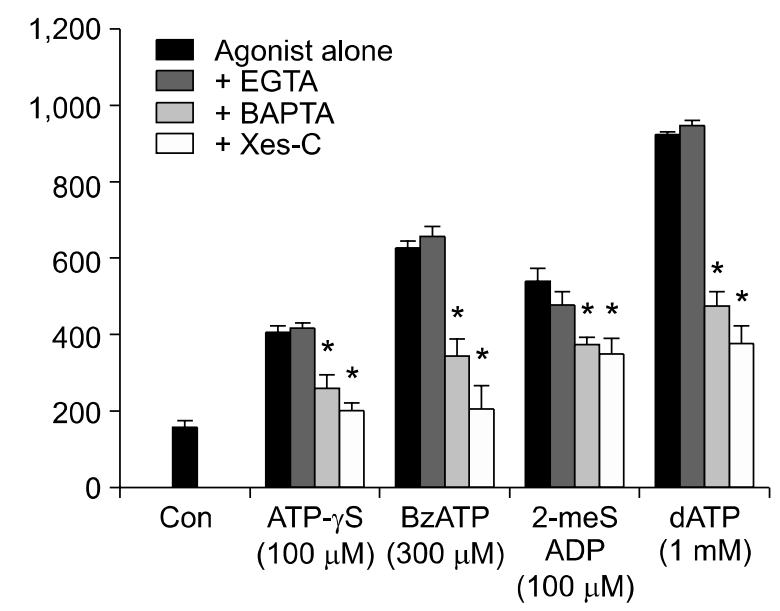

B

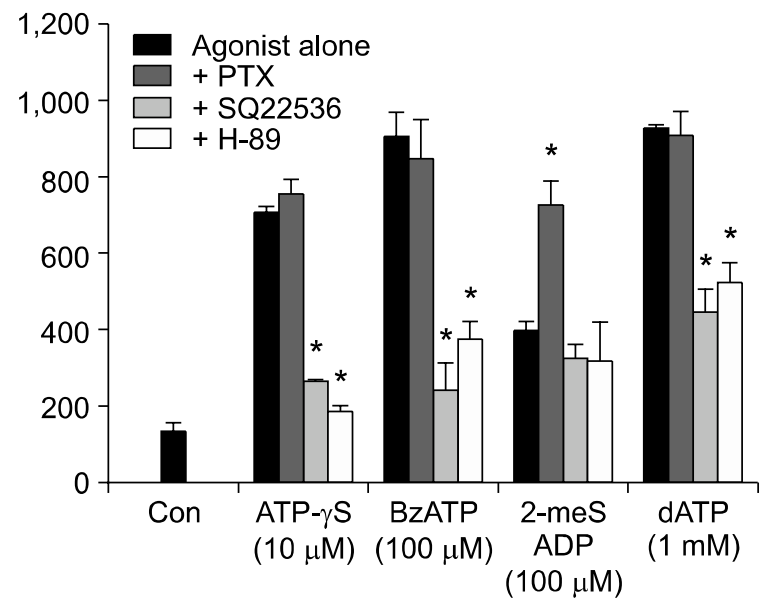

Figure 5. Effects of the calcium chelators and inhibitor of $\mathrm{IP}_{3}$, adenylate cyclase, or PKA on IL-10 release from microglial cells. Microglial cells $\left(3 \times 10^{4}\right.$

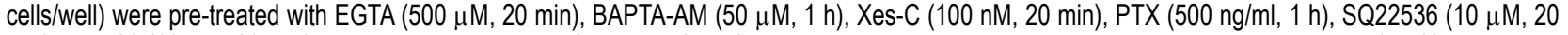
$\mathrm{min})$, or $\mathrm{H}-89(10 \mu \mathrm{M}, 20 \mathrm{~min})$, then treated with ATP- $\gamma-\mathrm{S}$, BzATP, 2-meSADP, and dATP at the indicated concentrations. The amount of IL-10 was measured $24 \mathrm{~h}$ after treatment. Data shown are mean \pm SEM of triplicate samples. The figure shows one representative of three independent experiments. ${ }^{*} P$

$<0.01$ compared to agonist alone.

\section{Effects of $\mathrm{Ca}^{2+}$ chelators and the inhibitors of $\mathrm{IP}_{3}$, adenylate cyclase, and PKA on IL-10 release from microglial cells}

We investigated the effects of BAPTA-AM (a membrane permeable $\mathrm{Ca}^{2+}$ chelator) and Xes-C (an $\mathrm{IP}_{3}$ inhibitor) on the IL-10 production. As expected, ATP- $\gamma S(100 \mu \mathrm{M})$, BzATP $(300 \mu \mathrm{M})$, dATP $(1 \mathrm{mM})$, and 2-meSADP $(100 \mu \mathrm{M})$-induced IL-10 expression was down-regulated with BAPTA-AM or Xes-C treatment, indicating that intracellular $\mathrm{Ca}^{2+}$ release contributes the IL-10 production. However, IL-10 production by ATP- $\gamma \mathrm{S}(100 \mu \mathrm{M})$ or BzATP $(300 \mu \mathrm{M})$ was not affected when the cells were preincubated in EGTA-containing $\mathrm{Ca}^{2+}$-free medium, indicating that $\mathrm{Ca}^{2+}$ influx through $\mathrm{P} 2 \mathrm{X}_{1}, \mathrm{P}_{2} \mathrm{X}_{3}$, $\mathrm{P}_{2} \mathrm{X}_{4}, \mathrm{P} 2 \mathrm{X}_{7}$ receptor group did not inhibit the IL-10 production (Figure $5 \mathrm{~A}$ ). As can be seen in Figure 5B, ATP- $\gamma \mathrm{S}(10 \mu \mathrm{M})$, BzATP $(100 \mu \mathrm{M})$, and dATP (1 $\mathrm{mM}$ )-induced IL-10 production was down-regulated by SQ22536 (an adenylate cyclase inhibitor) or $\mathrm{H}-89$ (a PKA inhibitor), and 2-meSADP $(100 \mu \mathrm{M})$-induced IL-10 production was more upregulated by pertussis toxin (PTX; a $G_{i}$ protein inhibitor). These results suggest that intracellular $\mathrm{Ca}^{2+}$ release and/or cAMP-activated PKA are the main contributors to extracellular ATP-(or ADP)mediated IL-10 expression.

\section{Discussion}

In this study, we presented evidences for crosstalk between $\mathrm{P} 2$ receptors in a situation where $\mathrm{P} 2 \mathrm{Y}_{1}$ and $\mathrm{P} 2 \mathrm{Y}_{11}$ receptors are major receptors involved in extracellular ATP-(or ADP)-mediated IL-10 production, and $\mathrm{P} 2 \mathrm{X}_{1}, \mathrm{P} 2 \mathrm{X}_{3}, \mathrm{P} 2 \mathrm{X}_{4}$ receptor group, or the $P 2 Y_{12}$ receptor, negatively modulate the $P 2 Y_{11}$ receptor or the $\mathrm{P} 2 \mathrm{Y}_{1}$ receptor, respectively.

The $P 2 Y_{1}$ and $P 2 Y_{11}$ receptors are coupled to $G_{q}$, promoting PLC-catalyzed generation of an $\mathrm{IP}_{3}$, and subsequent release of intracellular calcium (Ralevic and Burnstock, 1998). Therefore, we investigated the effects of BAPTA-AM and Xes-C (an $\mathrm{IP}_{3}$ inhibitor) on IL-10 production. As expected, the IL-10 expression induced by ATP- $\gamma \mathrm{S}(100 \mu \mathrm{M})$, BzATP $(300 \mu \mathrm{M})$, dATP $(1 \mathrm{mM})$, or 2-meSADP $(100 \mu \mathrm{M})$ was down-regulated by BAPTA-AM or Xes-C treatment, indicating that intracellular $\mathrm{Ca}^{2+}$ release contributes to IL-10 production (Figure $5 \mathrm{~A}$ ). In accord with these results, previous study demonstrated that $\mathrm{Ca}^{2+}$ and calmodulin (CaM) stimulated adenylate cyclase (Simonds, 1999), and that prostaglandin $E_{2}\left(P_{G} E_{2}\right)$, which was shown to accumulate CAMP in microglia, enhanced the LPSinduced IL-10 expression by microglia (Patrizio et al., 1996; Aloisi et al., 1999).

Previous work has shown that agonists for the $\mathrm{P}_{2 Y_{11}}$ receptor are ATP- $\gamma \mathrm{S}$, BzATP, ATP, and ADP- $\beta S$ (Communi et al., 1999). Indeed, exposure to these nucleotides increased the release of IL-10 (Figures 1 and 3 ), and IL-10 release mediated by ATP- $\gamma \mathrm{S}(10 \mu \mathrm{M})$, BzATP $(100 \mu \mathrm{M})$, and dATP $(1$ $\mathrm{mM}$ ) was down-regulated by an adenylate cyclase inhibitor, SQ22536, and a PKA inhibitor, H-89 (Figure 5B). These results are consistent with 
previous findings that $P 2 Y_{11}$ receptors activate adenylate cyclase and contribute to cAMP formation (Torres et al., 2002). Recent studies showed that ATP- $\gamma S$ enhanced LPS-induced IL-10 production in human monocyte-derived dendritic cells (Marteau et al., 2004), and that ATP- $\gamma$ S and BzATP inhibited the production of TNF- $\alpha, \quad \mathrm{IL}-8$, and MIP-1 $\beta$ in human mast cells through a $G_{s}$-coupled receptor (Feng et al., 2004). At this point, we can not rule out the involvement of other $\mathrm{P}_{2} \mathrm{Y}_{11}$ receptor subtypes in our study, as BzATP $(100 \mu \mathrm{M})$-induced IL-10 release was only partially inhibited by 5'AMPS (a P2Y 11 antagonist) (Figure 4D), and P2Y 11 receptor-transcripts have not been found in rats and mice (von Kügelgen, 2006). To date, the $\mathrm{P}_{2} \mathrm{Y}_{11}$ receptor is the only cloned ATP-binding P2Y family member known to stimulate $\mathrm{G}_{\mathrm{s}}$ proteins (Communi et al., 1999).

Data from work with agonists indicated that the $\mathrm{P} 2 \mathrm{X}$ receptors did not contribute to IL-10 production (Figure 3), but TNP-ATP (an antagonist of the $\mathrm{P} 2 \mathrm{X}_{1}, \mathrm{P} 2 \mathrm{X}_{3}$, and $\mathrm{P} 2 \mathrm{X}_{4}$ receptors) up-regulated ATP$\gamma \mathrm{S}(100 \mu \mathrm{M})$-induced IL-10 production (Figure 4A). These results suggest that there is reciprocal crosstalk between the $\mathrm{P} 2 \mathrm{Y}_{11}$ and $\mathrm{P} 2 \mathrm{X}$ receptors, through which plasma membrane depolarization by $\mathrm{Na}^{+}$and $\mathrm{Ca}^{2+}$ entry from the extracellular space negatively modulates IL-10 expression. Previous study showed that depolarization induced by P2X receptor-mediated $\mathrm{Na}^{+}$influx inhibited store-operated channels (SOC)-mediated $\mathrm{Ca}^{2+}$ entry resulting from P2Y activation (Wang et al., 2000). Therefore, down-regulation of IL-10 production by 100 $\mu \mathrm{M}$ ATP- $\gamma \mathrm{S}$ may be mediated by $\mathrm{P} 2 \mathrm{X}_{1}, \mathrm{P} 2 \mathrm{X}_{3}$, and $\mathrm{P}_{2} \mathrm{X}_{4}$ receptors-mediated inhibition of $\mathrm{Ca}^{2+}$ entry through SOC.

Unlike the $G_{q}$-coupled $P 2 Y_{1}$ receptor, the ADPselective $P 2 Y_{12}$ and $P 2 Y_{13}$ receptors both use $G_{i}$ proteins to inhibit adenylate cyclase (Communi et al., 2001). In accord with these data, our results showed that $100 \mu \mathrm{M}$ 2-meSADP-induced IL-10 production was up-regulated by 2 meSAMP (a $\mathrm{P}_{2} \mathrm{Y}_{12}$ antagonist) and PTX (a P2Y 12 receptor inhibitor), but down-regulated by MRS2179 (a P2Y antagonist) (Figure 4B and $5 \mathrm{~B}$ ), indicating reciprocal crosstalk between $\mathrm{P}_{2} \mathrm{Y}_{1}$ and $\mathrm{P}_{2} \mathrm{Y}_{12}$ receptors. Crosstalk between the downstream pathways of $\mathrm{P}_{2} \mathrm{Y}_{1}$ and $\mathrm{P}_{2} \mathrm{Y}_{12}$ receptors was demonstrated in the regulation of platelet aggregation and astrocytes cell death (Hardy et al., 2004; Mamedova et al., 2006).

In conclusion, our study provides evidence that extracellular ATP-(or ADP)-mediated IL-10 production in microglia is mediated via $P 2 Y_{1}$ and $P 2 Y_{11}$. Further, IL-10 production is modulated by crosstalk between $P 2 Y_{1}$ and $P 2 Y_{12}$ receptors, and $P 2 Y_{11}$ and $\mathrm{P} 2 \mathrm{X}$ receptors.

\section{Acknowledgements}

This work was supported by the Korea Science and Engineering Foundation (KOSEF) through the Brain Disease Research Center at Ajou University.

\section{References}

Abbracchio MP, Burnstock G, Boeynaems JM, Barnard EA, Boyer JL, Kennedy C, Knight GE, Fumagalli M, Gachet C, Jacobson KA. International Union of Pharmacology LVIII: update on the $\mathrm{P} 2 \mathrm{Y} \mathrm{G}$ protein-coupled nucleotide receptors: from molecular mechanisms and pathophysiology to therapy. Pharmacol Rev 2006;58:281-341

Aloisi F, De Simone R, Columba-Cabezas S, Levi G. Opposite effects of interferon- $\gamma$ and prostaglandin $E_{2}$ on tumor necrosis factor and interleukin-10 production in microglia: a regulatory loop controlling microglia pro- and anti-inflammatory activities. J Neurosci Res 1999;56:571-80

Brunschweiger A, Muller CE. P2 receptors activated by uracil nucleotides--an update. Curr Med Chem 2006;13:289-312

Communi D, Pirotton S, Parmentier M, Boeynaems JM. Cloning and functional expression of a human uridine nucleotide receptor. J Biol Chem 1995;270:30849-52

Communi D, Govaerts C, Parmentier M, Boeynaems JM. Cloning of a human purinergic $\mathrm{P} 2 \mathrm{Y}$ receptor coupled to phospholipase C and adenylyl cyclase. J Biol Chem 1997; 272:31969-73

Communi D, Robaye B, Boeynaems JM. Pharmacological characterization of the human P2Y11 receptor. Br J Pharmacol 1999;128:1199-206

Communi D, Gonzalez NS, Detheux M, Brezillon S, Lannoy V, Parmentier M, Boeynaems JM. Identification of a novel human ADP receptor coupled to $\mathrm{G}_{\mathrm{i}}$. J Biol Chem 2001;276: 41479-85

Di Virgilio F, Sanz JM, Chiozzi P, Falzoni S. The P2Z/P2X7 receptor of microglial cells: a novel immunomodulatory receptor. Prog Brain Res 1999;120:355-68

Di Virgilio F, Solini A. P2 receptors: new potential players in atherosclerosis. Br J Pharmacol 2002;135:831-42

Feng C, Mery AG, Beller EM, favot C, Boyce JA. Adenine nucleotides inhibit cytokine generation by human mast cells through a $\mathrm{G}_{\mathrm{s}}$-coupled receptor. J Immunol 2004;173:753947

Hardy AR, Jones ML, Mundell JS, Poole AW. Reciprocal cross-talk between $\mathrm{P}_{2} \mathrm{Y}_{1}$ and $\mathrm{P} 2 \mathrm{Y}_{12}$ receptors at the level of calcium signaling in human platelets. Blood 2004;104: 1745-52

Haynes SE, Hollopeter G, Yang G, Kurpius D, Dailey ME, Gan WB, Julius D. The P2Y 12 receptor regulates microglial activation by extracellular nucleotides. Nat Neurosci 2006; 9:1512-9

Hide I, Tanaka M, Inoue A, Nakajima K, Kohsaka S, Inoue K, Nakata Y. Extracellular ATP triggers tumor necrosis factor- $\alpha$ release from rat microglia. J Neurochem 2000;75:965-72 
Hollopeter G, Jantzen HM, Vincent D, Li G, England L, Ramakrishnan V, Yang RB, Nurden P, Nurden A, Julius D. Identification of the platelet ADP receptor targeted by antithrombotic drugs. Nature 2001;409:202-7

Khakh BS, North RA. P2X receptors as cell-surface ATP sensors in health and disease. Nature 2006;442:527-32

Kim KY, Kim MY, Choi HS, Jin BK, Kim SU, Lee YB. Thrombin induces IL-10 production in microglia as a negative feedback regulator of TNF-alpha release. Neuroreport 2002;13:84952

Koizumi S, Shigemoto-Mogami Y, Nasu-Tada K, Shinozaki Y, Ohsawa K, Tsuda M, Joshi BV, Jacobson KA, Kohsaka S, Inoue K. UDP acting at $\mathrm{P}_{2} \mathrm{Y}_{6}$ receptors is a mediator of microglial phagocytosis. Nature 2007;446:1091-5

Light AR, Wu Y, Hughen RW, Guthrie PB. Purinergic receptors activating rapid intracellular $\mathrm{Ca}^{2+}$ increases in microglia. Neuron Glia Biol 2006;2:125-38

Lustig KD, Shiau AK, Brake AJ, Julius D. Expression cloning of an ATP receptor from mouse neuroblastoma cells. Proc Natl Acad Sci USA 1993;90:5113-7

Mamedova LK, Gao ZG, Jacobson KA. Regulation of death and survival in astrocytes by ADP activating $P 2 Y_{1}$ and $P 2 Y_{12}$ receptors. Biochem Pharmacol 2006;72:1031-41

Marteau F, Communi D, Boeynaems JM, Gonzalez NS. Involvement of multiple $\mathrm{P} 2 \mathrm{Y}$ receptors and signaling pathways in the action of adenine nucleotides diphosphates on human monocyte-derived dendritic cells. J Leukoc Biol 2004;76:796-803

Ohtani Y, Minami M, Satoh M. Expression of inducible nitric oxide synthase mRNA and production of nitric oxide are induced by adenosine triphosphate in cultured rat microglia. Neurosci Lett 2000;293:72-4

Parvathenani LK, Tertyshnikova S, Greco CR, Roberts SB, Robertson B, Posmantur R. P2 $\mathrm{X}_{7}$ mediates superoxide production in primary microglia and is up-regulated in a transgenic mouse model of Alzheimer's disease. J Biol

\section{Chem 2003;278:13309-17}

Patrizio M, Costa T, Levi G. Interferon- $\gamma$ and lipopolysaccharide reduce cAMP responses in cultured glial cells: reversal by a type IV phosphodiesterase inhibitor. Glia 1996;14:94-100

Ralevic V, Burnstock G. Receptors for purines and pyrimidines. Pharmacol Rev 1998;50:413-92

Sanz JM, Di Virgilio F. Kinetics and mechanism of ATPdependent IL-1 $\beta$ release from microglial cells. J Immunol 2000;164:4893-8

Seo DR, Kim KY, Lee YB. Interleukin-10 expression in lipopolysaccharide-activated microglia is mediated by extracellular ATP in an autocrine fashion. Neuroreport 2004;15:1157-61

Shigemoto-Mogami Y, Koizumi S, Tsuda M, Ohsawa K, Kohsaka S, Inoue K. Mechanisms underlying extracellular ATP-evoked interleukin-6 release in mouse microglial cell line, MG-5. J Neurochem 2001;78:1339-49

Simonds WF. G protein regulation of adenylate cyclase. Trends Pharmacol Sci 1999;20:66-73

Torres B, Zambon AC, Insel PA. P2Y 11 receptors activate adenylyl cyclase and contribute to nucleotide-promoted cAMP formation in MDCK-D ${ }_{1}$ cells. A mechanism for nucleotide-mediated autocrine-paracrine regulation. J Biol Chem 2002;277:7761-5

Tsuda M, Shigemoto-Mogami Y, Koizumi S, Mizokoshi A, Kohsaka S, Salter MW, Inoue K. P2X receptors induced in spinal microglia gate tactile allodynia after nerve injury. Nature 2003;424:778-83

von Kügelgen I. Pharmacological profiles of cloned mammalian P2Y-receptor subtypes. Pharmacol Ther 2006;110: 415-32

Wang X, Kim SU, van Breemen C, McLarnon JG. Activation of purinergic $\mathrm{P} 2 \mathrm{X}$ receptors inhibits $\mathrm{P} 2 \mathrm{Y}$-mediated $\mathrm{Ca}^{2+}$ influx in human microglia. Cell Calcium 2000;27:205-12 